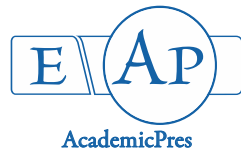

\title{
Effect of Exogenous Application of Several Plant Growth Regulators on Photosynthetic Pigments of Fennel Plants
}

\author{
Ghasem PARMOON ${ }^{1 *}$, Ali EBADI ${ }^{1}$, Soodabe JAHANBAKHSH ${ }^{1}$, \\ Masoud HASHEMI², Seyed Amir MOOSAVI ${ }^{3}$ \\ ${ }^{1}$ University of Mohaghegh Ardabili, Department of Agronomy and Plant Breeding, Faculty of Agriculture and Natural Resources, Ardabil, \\ Iran;ghasem.parmoon@gmail.com (*correspondingauthor); ebadi@uma.ac.ir,Jahanbakbsh@uma.ac.ir \\ ${ }^{2}$ University of Massachusetts Amherst, Stockbridge School of Agriculture, Massachusetts, USA; masoud@umass.edu \\ ${ }^{3}$ Agricultural Sciences and Natural Resources University of Khuzestan, Department of Plant production and genetics, Faculty of Agriculture, \\ Khuzestan,Iran;amir.msa@gmail.com; amirmoosavi@ramin.ac.ir
}

\begin{abstract}
In order to investigate the effects of some plant growth regulators on photosynthetic pigments and growth of fennel plants, a greenhouse experiment was conducted based on the randomized complete block design with three replicates in 2017. Treatments were the application of methyl jasmonate $(25,50,100$ and $200 \mu \mathrm{M})$, putrescine $(0.25,0.5,1$ and $2 \mathrm{mM})$ and 24Epibrassinolide at $0.001,0.01,0.1$ and $1 \mu \mathrm{M}$ and distilled water as a control. The results indicated that application of $0.5 \mathrm{Mm}$ putrescine, exhibited significant effects on the chlorophyll a (62\%), b (104\%), total chlorophyll (72\%), carotenoids (51\%), flavonoids (51\%), anthocyanin content (-14\%), phenolic compounds (13\%) and maximum quantum efficiency (17\%) in dark condition and in light condition. Application of 24-Epibrassinolide resulted in a significant increase of chlorophyll a and total chlorophyll, carotenoids, phenol content, maximum quantum efficiency in the dark condition and photochemical quenching of fluorescence. The highest chlorophyll content and carotenoids were observed in treated plants with $0.1 \mu \mathrm{M} \mathrm{24-}$ Epibrassinolide, while the maximum phenol content was obtained by application of $0.01 \mu \mathrm{M}$ 24-Epibrassinolide. The application of methyl jasmonate significantly affected the major chlorophyll and accessory pigments (except phenol) of fennel. Plants treated with $50 \mu \mathrm{M}$ methyl jasmonate exhibited higher concentrations of chlorophyll a (3.25 mg per $\left.\mathrm{g} \mathrm{FW}^{-1}\right)$, total chlorophyll ( $4.35 \mathrm{mg}$ per g FW $\left.\mathrm{FW}^{-1}\right)$, carotenoids $\left(0.87 \mathrm{mg}\right.$ per $\left.\mathrm{g} \mathrm{FW}^{-1}\right)$ and flavonoids $\left(4.75 \mu \mathrm{g}\right.$ per $\left.\mathrm{g} \mathrm{FW}^{-1}\right)$. A significant dry weight increased after the application of methyl jasmonate and it can be concluded that the most effective treatment in this regard for fennel plants was $50 \mu \mathrm{M}$ methyl jasmonate.
\end{abstract}

Keywords: anthocyanin; chlorophyll; fennel; jasmonate; phytohormone

\section{Introduction}

Foeniculum vulgare Mill or fennel is an important medicinal plant belongs to the Apiaceae family. Fennel is originated from the Mediterranean area and widely been cultivated around the world (Mahfouz and Sharaf-Eldin, 2007; Aprotosoaie et al., 2010). Fruits and essential oil of fennel are used as flavouring agents in food, pharmaceutical products and cosmetic industry (Diao et al., 2014). Essential oil constituent of fennel contained mainly: estragole, transanethole, cis-anethole, fenchone and limonene (DíazMaroto et al., 2006; Rather et al., 2016). Fennel is recognized as well as an important plant in pharmaceutical and used as a stimulant, diuretic, sedative, digestive, carminative, antispasmodic and expectorant (Hashmi $e t$ al., 2012).
Application of plant growth regulators (PGRs) is a management method in modern agriculture and production systems, which have significantly enhance the agricultural inputs use efficiency (Berry et al., 2007). The PGRs could regulate many of the physiologic processes in plants, furthermore, enhance resistance to various environmental stresses (Akram and Ashraf, 2013; Asgher et al., 2015). Methyl jasmonate (MJs), 24-epibrassinolide (BRs) and Putrescine (Put) are PGRs that in the last years have been successfully incorporated into crop production (Eyidogan et al., 2012) of cucumber (Shu et al., 2012), soybean (Cevahir et al., 2008), Broad bean (Piñol and Simón 2009), and Runner bean (Hanaka et al., 2015).

Polyamines (PAs) are small aliphatic amines, which behaved as a promoter of many plant physiological processes

Received: 31 Aug 2018. Received in revised form: 10 Dec 2018. Accepted: 14 Dec 2018. Published online: 21 Dec 2018. 
such as cell division and tissue growth and development (Hasanuzzaman et al., 2014). Currently, putrescine, spermidine, and spermine are most well-known PAs. These compounds are organic polycations and exist in all organs of the plant, which have been associated with plant response to environmental stress (Alcázar et al., 2010). The PAs have substantial roles in DNA, RNA and protein synthesis (Igarashi and Kashiwagi, 2000). The PAs affect different plant developmental processes. For instance, Mahros et al. (2011), reported that the application of Put led to decline of pedicle and flower stalk length. However, Put significantly increased flower yield, chlorophyll $\mathrm{a}, \mathrm{b}$ and the total carbohydrates. Likewise, photosynthetic pigments of African violet (Saintpaulia ionantha) were significantly increased by application of putrescine (Nanvakenary et al., 2013). In cucumber, exogenous application spermidine significantly increased chlorophyll contents and net photosynthetic rate $\left(\mathrm{P}_{\mathrm{N}}\right)$ and decreased constitutive loss processes ( $\Phi N O)$ and enhanced regulated nonphotochemical energy loss ( $\Phi N P Q)$ in the salt-stressed plants (Shu et al., 2012).

The MJs are found naturally in plants and they are responsible for regulation of many physiological and metabolic processes. Application of MJs improved plant resistance to various abiotic stresses (Bari and Jones, 2009). The MJs may influence Rubisco activity as well as the synthesis of other chloroplast proteins responsible for photosynthesis (Marín-Navarro et al., 2007). It was reported that MJs treatment of soybean appeared to arrest the growth, impaired leaf gas-exchange attributes and caused the loss of chlorophyll contents under water deficit conditions (Anjum et al., 2011). In another experiment, MJs increased leaf area, photosynthetic pigments and decreased chlorophyll fluorescence in Phaseolus coccineus plants (Hanaka et al., 2015).

The BRs have been recognized as polyhydroxysteroids, which play a fundamental role in many of the physiological and developmental processes of plants. It is reported that the BRs regulate seed germination, time of flowering, and maturation (Vardhini et al., 2006; Tang et al., 2016), Moreover, they are one of determining factor which confer plants resistance to environmental stresses (Fariduddin $e t$ al., 2014). Furthermore, BRs plays important roles in cellular responses such as stem elongation, pollen tube growth, leaf bending and epinasty, ethylene biosynthesis, xylem differentiation, and regulation of gene expression (Houimli et al., 2008; Hayat et al., 2012). Cevahir et al. (2008) reported that the application of exogenous BRs significantly affected the production of plant pigments such as chlorophyll, carotenoids, and anthocyanin in soybean. However, this effect was depended on the light condition.

Application of various plant growth regulators for modifications of plant physiological responses and alleviate abiotic stresses damages to plants has been well documented (Gururani et al., 2015; Mo et al., 2016; Awan et al., 2017). However, the time of PGRs application and eventual impact on photosynthesis behaviours of fennel plants is still elusive. This study was therefore conducted to study the photosynthesis potential and relative performance of fennel pigments obtained from PGRs treated plants.

\section{Materials and Methods}

\section{Plant material and growth condition}

A greenhouse experiment was conducted at the Faculty of Agriculture and Natural Resources, University of Mohaghegh Ardabili, Ardabil, Iran, in 2017.

Greenhouse condition was related to a day temperature of $24 \pm 2{ }^{\circ} \mathrm{C}$, a night temperature of $16 \pm 2{ }^{\circ} \mathrm{C}$ and a relative humidity of $50 \pm 5 \%$.

Each pot was filled with $20 \mathrm{~kg}$ sieved field soil. A soil sample taken prior to planting indicated soil $\mathrm{pH}$ (1:1, soil/ $\mathrm{H}_{2} \mathrm{O}$ ) was 7.9 , cation exchange capacity (CEC) was $0.625 \mathrm{ds} / \mathrm{m}$, and available $P, \mathrm{~K}$ were 8.5 and $0.6 \mathrm{mg} / \mathrm{kg}$, respectively. Ten seeds were planted in each pot and then thinned to five seedlings per pot once plants were wellestablished.

Treatments were arranged as a randomized complete block design with three replicates. Treatments application MJs include 25, 50, 100 and $200 \mu \mathrm{M}$, Put include 0.25, 0.5, 1 and $2 \mathrm{mM}$ and BRs at 0.001, 0.01, 0.1 and $1 \mu \mathrm{M}$ and distilled water as control were randomly assigned to the experimental pots. Treatments were imposed prior to the before flowering stage (65 days after planting) and 10 days after treatments imposed sampling for measured all parameters.

\section{Determination of photosynthetic pigment}

Chlorophyll a, b, total chlorophyll and carotenoids content were measured using the method described by Arnon (1967). For the extraction of pigments, $0.1 \mathrm{~g}$ of fresh tissue leaves were homogenized with acetone $80 \%$, then the volume of the solution was reached to $20 \mathrm{ml}$ by acetone $80 \%$. Final solution centrifuged at 4,000 rpm at $10 \mathrm{~min}$ and optical absorption of the supernatant was performed in wavelengths 470, 645 and $663 \mathrm{~nm}$. Chlorophyll content and carotenoids according to $\mathrm{mg}$ per $\mathrm{g}$ fresh weight were determined by following equations:

Chlorophyll $\mathrm{a}=\left(19.3 \times \mathrm{A}_{663}-0.86 \times \mathrm{A}_{645}\right) \mathrm{V} / 100 \mathrm{~W}$

Chlorophyll b $=\left(19.3 \times \mathrm{A}_{645}-3.6 \times \mathrm{A}_{663}\right) \mathrm{V} / 100 \mathrm{~W}$

Total Chlorophyll $=$ Chlorophyll $\mathrm{a}+$ Chlorophyll b

Carotenoids $=\left(1000 \mathrm{~A}_{470}-1.82 \times \mathrm{Ca}-85.02 \times \mathrm{Cb}\right) / 198$

\section{Determination of anthocyanin and total phenol}

For detriment anthocyanin content of fresh tissue, $0.1 \mathrm{~g}$ of leaves was homogenized with $10 \mathrm{ml}$ ethanol acid (ethanol: $\mathrm{HCl} 99: 1 \mathrm{v} / \mathrm{v}$ ) and the solution was kept at in dark and $25{ }^{\circ} \mathrm{C}$ condition. Then solution centrifuged in 4,000 rpm at $10 \mathrm{~min}$ and absorbance was measured in wavelengths $550 \mathrm{~nm}$. Anthocyanin content according to $\mathrm{mg} / \mathrm{g}$ fresh weight (Wagner, 1979).

Total phenol content determined using Folin-Ciocalteu method described by Fletcher and Kott (1999). In brief, 0.1 g of leaves was homogenized with $10 \mathrm{ml}$ ethanol $96 \%$, then crude extract was allowed to stand for a further 24 hours in the dark. In finally, $1 \mathrm{ml}$ ethanol $95 \%, 0.5 \mathrm{ml}$ folin $50 \%$ and $1 \mathrm{ml}$ sodium carbonate 5\% addition to extract and the mixture was kept for 1 hour in dark condition. Absorbance was measured at $725 \mathrm{~nm}$ and total phenolic was calculated from the calibration curve, and the results were expressed as $\mathrm{mg}$ of gallic acid equivalent per $\mathrm{g}$ fresh weight. 
510

\section{Determination offlavonoids}

The flavonoid was determined according to Krizek et al. (1998) methods, in order to $0.1 \mathrm{~g}$ from leaves extract in ethanol acid (ethanol: glacial acetic 99:1 v/v) and solution centrifuged in 3,600 rpm at $10 \mathrm{~min}$. The supernatant was separate and allowed to stand for a further $10 \mathrm{~min} 80^{\circ} \mathrm{C}$. Finally, the absorbance was measured in three wavelengths 270,300 and $330 \mathrm{~nm}$.

\section{Determination of chlorophyll fluorescence}

Chlorophyll fluorescence was measured on the uppermost fully expanded leaf by using a fluorometer (model: OS-30P+ chlorophyll Fluorometer, Optic Science, USA). In this method, plants were adapted to darkness using dark adaptation clip for 15 minutes and then the fluorescence was measured in $1,000 \mu \mathrm{M}$ photon $\mathrm{m}^{-2} \mathrm{~s}^{-1}$ by illumination of far-red light and calculated using the following equations (Arnon, 1949): In these equations, $\mathrm{F}^{\prime} \mathrm{v} / \mathrm{F}^{\prime} \mathrm{m}$ is maximum quantum efficiency of PSII photochemistry in the light-adapted state, PSII equivalent maximum quantum efficiency of PSII photochemistry in the dark-adapted state, $\mathrm{qP}$ or photochemical quenching of fluorescence and NPQ is non-photochemical quenching.

$\mathrm{F}^{\prime} \mathrm{v} / \mathrm{F}^{\prime} \mathrm{m}=\left(\mathrm{F}^{\prime} \mathrm{m}-\mathrm{F}^{\prime} \mathrm{O}\right) / \mathrm{Fm}^{\prime}$

$\mathrm{PSII}=\left(\mathrm{F}^{\prime} \mathrm{m}-\mathrm{Fs}\right) / \mathrm{Fm}^{\prime}$

$\mathrm{qP}=\left(\mathrm{F}^{\prime} \mathrm{m}-\mathrm{Fs}\right) / \mathrm{F}^{\prime} \mathrm{m}-\mathrm{Fo}^{\prime}$

$N P Q=\left(F m-F^{\prime} m\right) / F^{\prime} m$

$\mathrm{F}_{\mathrm{m}}$ (maximum fluorescence) after a saturated light pulse on plants adapted to darkness, and $\mathrm{F}_{0}$ (minimum fluorescence) when all PSII reaction centers (RCs) open. $\mathrm{F}_{\mathrm{m}}^{\prime}$ and $\mathrm{F}_{\mathrm{o}}^{\prime}$ also maximum and minimum fluorescence on plants adapted to light.

\section{Statistical analysis}

Analysis of variance (ANOVA) was performed using Minitab, Ver, 16. The least significant difference (LSD) was used for mean separation and data is shown as a mean \pm standard error (SE). Sigma plot v. 11 was used to calculate the regression equation. The reliability of models was evaluated using the coefficient of determination $\left(R^{2}\right)$ and root-mean-square error (RMSE). In the present study, the parameters fitted by recon models (Table 1 ).

\section{Results and Discussion}

Effect of Put application on the fennel pigments and photosynthetic parameters

The results of the present study clearly showed that there was a significant effect of Put application on the chlorophyll a, b and total chlorophyll content of fennel leaves (Table 2). The Put application resulted in enhancement of chlorophyll content, which followed the Gaussian function. Leaves of treated plants with $0.5 \mathrm{mM}$ Put showed the highest chlorophyll $\mathrm{a}, \mathrm{b}$ and total content. Application of $0.5 \mathrm{mM}$ Put increased chlorophyll a, b and total chlorophyll content by approximately $63 \%, 105 \%$, and $73 \%$ respectively compared with control. Model analysis revealed that the maximum chlorophyll a, b and total chlorophyll were estimated by $0.65,0.72$ and $0.68 \mathrm{mM}$ put respectively (Table 2 ).

Accessory pigments including carotenoids, anthocyanin, flavonoids and phenol content were significantly affected by Put treatments (Table 2). Results showed that the changes of anthocyanin and phenol due to the application of Put is followed a Gaussian function while other carotenoids and flavonoids were following log-normal function. The highest carotenoids content $\left(0.82 \mathrm{mg}\right.$ per $\left.\mathrm{FW}^{-1}\right)$ and flavonoids (5.29 ug per $\mathrm{FW}^{-1}$ ) content was recorded at $0.5 \mathrm{mM}$ Put, which approximately showed an enhancement about $50 \%$ and $51 \%$ over control. The maximum anthocyanin $(11 \%$ higher than control) and phenol content (16\% higher than control) was an observation of 0.25 and $1 \mathrm{mM}$ Put respectively (Table 2 ).

The present results are in agreement with the results of previous studies which reported that there was a significant increase in total carbohydrates, chlorophyll a, b, carotenoids and $\mathrm{P}_{\mathrm{N}}$ in Chrysanthemum indicum and cucumber (Mahros et al., 2011; Shu et al., 2012). The Put might be involved in improving heat dissipation capacity and regulating the deepoxidation state of the xanthophyll cycle (Yuan et al., 2015). In addition, Put may improve the photosynthetic capacity of mesophyll cells by enhancing the carbon assimilation capacity (Araújo et al., 2011; Yuan et al., 2014).

Results of the present study showed that the application Put significantly affected the two parameters of chlorophyll fluorescence including PSII and $\mathrm{F}^{\prime} \mathrm{v} / \mathrm{F}^{\prime} \mathrm{m}$ (Table 2). PSII and $F^{\prime} v / F^{\prime} m$ in leaves of Put treated plants were higher than those of control plants. Maximum of PSII and F'v/F'm by change approximately $24 \%$ and $17 \%$ compared to control, were recorded when plants treated with $0.5 \mathrm{mM}$ of Put. Log normal and Gaussian functions were provided the best fit to data obtained from PSII F'v/F'm traits of Put treated plants, respectively (Table 2 ).

Application of Put was not significant for fluorescence parameters of $\mathrm{qP}$, and $\mathrm{F}_{\mathrm{v}} / \mathrm{F}_{0}$. Moreover, plant height and total dry weight were not affecting by the Put application (Table 2). Application of Put declined the $\Phi N O$ and enhanced regulated $\Phi$ NPQ in stressed plants (Nanvakenary et al., 2013). Some studies revealed that Put plays a role in protecting PSII against excessive energy through improving the thermal dissipation of the excitation energy (Rascher $e t$ al., 2000). The quantum functions of fennel leaves were significantly improved by Put application. The Put may be involved in alleviating the photoinhibition of UPSII and enhancing the photochemical quenching process (Yuan et al., 2014).

In addition, PAs can neutralize the negative charges of LHCII that, it is a putative site of $\mathrm{qE}$, a rapid phase of NPQ, so that repulsion between different complexes is minimized (Navakoudis et al., 2007).

Table 1. Models used to fit parameters measured of fennel

\begin{tabular}{ccc}
\hline Model & Formula & Parameters \\
\hline Gaussian & $\mathrm{Y}=\mathrm{y}_{0}+\mathrm{a} \times \exp \left(-5 \times((\mathrm{x}-\mathrm{x} 0) / \mathrm{b})^{2}\right)$ & a or upper asymptote, $\mathrm{b}$ was a slope, $\mathrm{x} 0 \mathrm{Critical} \mathrm{point} \mathrm{or} \mathrm{the} \mathrm{x}$ that \\
Log Normal & $\left.\mathrm{Y}=\mathrm{y}_{0}+\mathrm{a} \times \exp \left(-0.5 \times(\ln (\mathrm{x} / \mathrm{x} 0) / \mathrm{b})^{2}\right) / \mathrm{x}\right)$ & reached of a and $\mathrm{y} 0$ is a lower asymptote \\
Single & $\mathrm{Y}=\mathrm{y}_{0}+\mathrm{a} \times \exp (\mathrm{b} \times \mathrm{x})$ & $\mathrm{y}_{0}$ is a lower asymptote, $\mathrm{a}, \mathrm{b}$ and $\mathrm{c}$ are slope \\
Cubic & $\mathrm{Y}=\mathrm{y}_{0}+\mathrm{c} \times \mathrm{x}+\mathrm{b} \times \mathrm{x}^{2}+\mathrm{a} \times \mathrm{x}^{3}$ & \\
\hline
\end{tabular}


Table 2. Effect application of Put concentration on photosynthetic pigments, chlorophyll fluorescence parameters and biomass of fennel (Foeniculum vulgar Mill) leaves

\begin{tabular}{|c|c|c|c|c|c|c|c|c|c|c|}
\hline \multirow{2}{*}{\multicolumn{2}{|c|}{ Characteristic }} & \multicolumn{5}{|c|}{ Put concentration $(\mathrm{mM})$} & \multirow{2}{*}{ F value } & \multirow{2}{*}{ Estimated function } & \multirow{2}{*}{$\mathrm{R}^{2}$} & \multirow{2}{*}{ RMSE } \\
\hline & & 0 & 0.25 & 0.5 & 1 & 2 & & & & \\
\hline \multicolumn{11}{|c|}{ Major Chlorophyll } \\
\hline \multirow{2}{*}{${ }^{\dagger}$ Chlorophyll a } & means & $1.70 \pm 0.32$ & $1.99 \pm 0.35$ & $2.76 \pm 0.58$ & $2.18 \pm 0.58$ & $1.49 \pm 0.64$ & $10.9^{* *}$ & $Y=1.53+1.41 \times \exp \left(-.5 \times((x-0.65) / 0.27)^{2}\right)$ & 0.989 & 0.10 \\
\hline & $\%$ & - & 16.9 & 62.5 & 28.0 & -12.5 & & & & \\
\hline \multirow{2}{*}{${ }^{\dagger}$ Chlorophyll b } & means & $0.53 \pm 0.19$ & $0.58 \pm 0.21$ & $1.08 \pm 0.05$ & $0.92 \pm 0.17$ & $0.57 \pm 0.12$ & $4.88^{* *}$ & $Y=0.54+1.20 \times \exp \left(-.5 \times((x-0.72) / 0.17)^{2}\right)$ & 0.996 & 0.028 \\
\hline & $\%$ & - & 10.2 & 104.6 & 73.7 & 7.6 & & & & \\
\hline \multirow{2}{*}{$\begin{array}{l}{ }^{\dagger} \text { Total } \\
\text { chlorophyll }\end{array}$} & means & $2.23 \pm 0.48$ & $2.57 \pm 0.53$ & $3.85 \pm 0.54$ & $3.10 \pm 0.76$ & $2.06 \pm 0.72$ & $14.3^{* *}$ & $Y=2.11+2.29 \times \exp \left(-.5 \times((x-0.68) / 0.24)^{2}\right)$ & 0.996 & 0.092 \\
\hline & $\%$ & - & 15.3 & 72.5 & 38.9 & -7.8 & & & & \\
\hline \multicolumn{11}{|c|}{ Accessory Pigments } \\
\hline \multirow{2}{*}{${ }^{\dagger}$ Carotenoids } & means & $0.55 \pm 0.08$ & $0.61 \pm 0.09$ & $0.82 \pm 0.06$ & $0.82 \pm 0.05$ & $0.71 \pm 0.06$ & $18.7^{* *}$ & $Y=0.54+0.34 \times \exp (-0.5 \times(\ln (x / 1.43) / 0.75)$ & 0.963 & 0.047 \\
\hline & $\%$ & - & 11.1 & 50.8 & 50.2 & 30.1 & & $\left.\left.{ }^{2}\right) / \mathrm{x}\right)$ & & \\
\hline \multirow{2}{*}{${ }^{\dagger}$ Anthocyanin } & means & $0.55 \pm 0.08$ & $0.61 \pm 0.09$ & $0.47 \pm 0.11$ & $0.39 \pm 0.05$ & $0.19 \pm 0.06$ & $12.3^{*}$ & $Y=0.16+0.40 \times \exp \left(-.5 \times((x-0.05) / 0.84)^{2}\right)$ & 0.949 & 0.073 \\
\hline & $\%$ & - & 11.4 & -14.2 & -28.2 & -65.3 & & & & \\
\hline \multirow{2}{*}{${ }^{\dagger \dagger}$ Flavonoids } & means & $3.49 \pm 0.51$ & $3.88 \pm 0.56$ & $5.29 \pm 0.11$ & $4.85 \pm 0.25$ & $4.30 \pm 0.31$ & $6.13^{*}$ & $Y=3.49+1.62 \times \exp (-0.5 \times(\ln (x / 1.17) /$ & 0.912 & 0.42 \\
\hline & $\%$ & - & 11.0 & 51.4 & 38.8 & 23.0 & & $\left.(0.70)^{2}\right) / \mathrm{x}$ & & \\
\hline \multirow{2}{*}{${ }^{\dagger}$ Phenol } & means & $1.02 \pm 0.04$ & $1.13 \pm 0.04$ & $1.14 \pm 0.02$ & $1.18 \pm 0.01$ & $1.09 \pm 0.01$ & $6.39^{* *}$ & $Y=1.53+1.41 \times \exp \left(-.5 \times((x-0.65) / 0.27)^{2}\right)$ & 0.903 & 0.038 \\
\hline & $\%$ & - & 11.1 & 12.8 & 16.3 & 7.5 & & & & \\
\hline \multicolumn{11}{|c|}{ Chlorophyll fluorescence: } \\
\hline \multirow[t]{2}{*}{ PSII } & means & $0.723 \pm 0.04$ & $0.903 \pm 0.06$ & $0.893 \pm 0.01$ & $0.793 \pm 0.00$ & $0.787 \pm 0.00$ & $5.51^{*}$ & $\begin{array}{c}\mathrm{Y}=0.72+0.090 \times \exp (-0.5 \times(\ln (\mathrm{x} / 1.06) / \\
\left.\left.1.22)^{2}\right) / \mathrm{x}\right)\end{array}$ & 0.944 & 0.036 \\
\hline & $\%$ & - & 24.90 & 23.51 & 9.68 & 8.85 & & & & \\
\hline \multirow{2}{*}{$\mathrm{qP}$} & means & $0.903 \pm 0.05$ & $0.940 \pm 0.01$ & $1.073 \pm 0.06$ & $0.917 \pm 0.02$ & $0.910 \pm 0.05$ & $2.35^{\mathrm{ns}}$ & $Y=0.90+0.18 \times \exp \left(-.5 \times((x-0.57) / 0.177)^{2}\right)$ & 0.998 & 0.005 \\
\hline & $\%$ & - & 4.10 & 18.83 & 1.55 & 0.78 & & & & \\
\hline \multirow{2}{*}{ NPQ } & means & $0.310 \pm 0.11$ & $0.277 \pm 0.10$ & $0.277 \pm 0.04$ & $0.333 \pm 0.15$ & $0.373 \pm 0.19$ & $0.19^{\mathrm{ns}}$ & $Y=0.310-0.214 x x+0.351 \times x^{2}-0.114 \times x^{3}$ & 1.000 & 0.00 \\
\hline & $\%$ & - & -10.8 & -10.8 & 7.5 & 20.4 & & & & \\
\hline \multirow{2}{*}{$\mathrm{F}^{\prime} \mathrm{v} / \mathrm{F}^{\prime} \mathrm{m}$} & means & $0.827 \pm 0.01$ & $0.847 \pm 0.02$ & $0.967 \pm 0.06$ & $0.853 \pm 0.01$ & $0.840 \pm 0.00$ & $5.05^{*}$ & $Y=0.83+0.187 \times \exp \left(-.5 \times((x-0.63) / 0.169)^{2}\right)$ & 0.993 & 0.0093 \\
\hline & $\%$ & & 2.42 & 16.93 & 3.14 & 1.57 & & & & \\
\hline \multirow{2}{*}{$\mathrm{Fv} / \mathrm{F} 0$} & means & $2.46 \pm 0.47$ & $2.70 \pm 0.05$ & $2.71 \pm 0.42$ & $3.52 \pm 1.72$ & $3.24 \pm 2.14$ & $1.46^{\mathrm{ns}}$ & $Y=2.49+1.45 \times \exp \left(-.5 \times((x-1.42) / 0.49)^{2}\right)$ & 0.975 & 0.136 \\
\hline & $\%$ & - & 9.76 & 10.16 & 43.09 & 31.71 & & & & \\
\hline \multicolumn{11}{|c|}{ Growth plant } \\
\hline \multirow[t]{2}{*}{${ }^{++\dagger}$ Height plants } & means & $52.73 \pm 5.43$ & $54.20 \pm 5.70$ & $55.80 \pm 5.57$ & $51.60 \pm 1.51$ & $52.40 \pm 3.03$ & $0.57^{\mathrm{ns}}$ & \multirow[t]{2}{*}{$Y=52.13+3.76 \times \exp \left(-.5 \times((x-0.44) / 0.18)^{2}\right)$} & 0.949 & 0.751 \\
\hline & $\%$ & - & 2.8 & 5.8 & -2.1 & -0.6 & & & & \\
\hline \multirow{2}{*}{$\begin{array}{l}{ }^{\dagger} \text { Dry weight } \\
\text { plants }\end{array}$} & means & $7.21 \pm 0.68$ & $7.40 \pm 0.68$ & $8.38 \pm 1.23$ & $7.88 \pm 1.26$ & $6.68 \pm 0.64$ & $1.28^{\mathrm{ns}}$ & \multirow{2}{*}{$Y=6.77+1.77 \times \exp \left(-.5 \times((x-0.67) / 0.33)^{2}\right)$} & 0.951 & 0.285 \\
\hline & $\%$ & - & 2.7 & 16.2 & 9.3 & -7.3 & & & & \\
\hline
\end{tabular}

$\dagger \mathrm{mg}$ perg $\mathrm{FW}^{-1}$, †† $\mu \mathrm{g}$ perg $\mathrm{FW}^{-1}$ and $\dagger \dagger \dagger \mathrm{cm}$.

Effect of BRs application on the fennel pigments and photosynthetic parameters

Application of BRs exhibited a significant increase of chlorophyll a and total chlorophyll content compared to control while there was no significant effect on the chlorophyll b content (Table 3). Results showed that the highest chlorophyll content by approximately $133 \%$ and $154 \%$ of control treatment, obtained by the exogenous application of $0.1 \mu \mathrm{M}$ BRs on fennel plants. The Lognormal function was capable to provide the best fit for the variations of chlorophyll content in treated plants. The slope of changes in chlorophyll a and total chlorophyll concentrations were estimated approximately 2.38 and 3.09 respectively (Table 3 ).

Among accessory pigments, only carotenoids and phenol content were influenced by the application of BRs. The accessory pigments of leaves were significantly improved by application of 0.1 and $0.01 \mu \mathrm{M}$ BRs and the carotenoids and phenol contents increased about $43 \%$ and $11 \%$ of control treatments, respectively (Table 3). Furthermore, it was found that BRs improved chlorophyll fluorescence parameters in fennel leaves. Results showed that PSII and $\mathrm{qP}$ were significantly increased in BRs treated plants. The Log normal function provided the best fit for the PSII and qP parameters. Plants treated with 0.01 and $0.1 \mu \mathrm{M}$ Put exhibited higher chlorophyll fluorescence parameters such as PSII and qP, which were increased 25\% and $11 \%$ higher than a control treatment (Table 3 ).

Although application of BRs did not significantly affects fennel growth, the overall trend of dry mater accumulation was followed a log-normal function. There are some reports showing that the application of BRs increases the chlorophyll, carotenoids and anthocyanin production in soybean (Cevahir et al., 2008). It has been reported that the exogenous application of BRs increased the pigment content in response to $\mathrm{NaCl}$ stress in some plants (Anuradha and Rao, 2003; Cevahir et al., 2008; Anuradha and RAO, 2011). Bajguz (2000) suggested that the BRs induced transcription and/or translation of the enzymes involved in chlorophyll biosynthesis linked with a decrease in the level of catabolizing enzymes. Piñol and Simón (2009) reported that the application of BRs led to palliative effects of terbutryn on fluorescence parameters, $\mathrm{CO}_{2}$ assimilation, and growth Vicia faba plants. It is suggested that the application of BRs could affect the terbutryn inhibition of PSII by displacement of QB from its binding site on the D1 protein of PSII. This protein is degraded when the photosynthetic system cannot process the energy of accumulated photons but little is known about the PSII repair process, either at the level of protein synthesis, insertion, and concomitant assembly of the $\mathrm{D}_{1}$ protein or at later functional post-translational assembly steps (Zhang et 
512

al., 2000). Thus, the $\mathrm{D}_{1}$ protein of PSII must be degraded, resynthesized de novo, and reinserted into the PSII reaction centre to repair the damage and re-establish PSII function (Piñol and Simón, 2009). It is known that BRs could influence the gene expression and protein synthesis. Thus, BRs could be implicated in the control of $\mathrm{D}_{1}$ damage and repair (Wang et al., 2006).

Effect of $M J$ s application on the fennel pigments and photosynthetic parameters

It was cleared that the exogenous application of MJs significantly affected the major chlorophyll and accessory pigments (except phenol) of fennel (Table 4). Lognormal provided the best fit for changes in major chlorophyll, carotenoids and flavonoids, whereas the Gaussian function well applied to describe the changes of anthocyanin in the MJs treated fennel leaves. The result indicated that exogenous MJs affect the chlorophyll concentration in treated plants. The maximum and minimum slope of variations in photosynthetic pigments was obtained 0.78 and 0.53 for chlorophyll $\mathrm{a}$ and $\mathrm{b}$, respectively (Table 4). Application of MJs enhanced total concentrations of the chlorophyll and accessory pigments. In comparison with control plants, treated plants with $50 \mu \mathrm{M}$ MJs exhibited $91 \%$, 95\%, 59\%, and 36\% chlorophyll a, total chlorophyll, carotenoids, and flavonoids, respectively (Table 4).

Marín-Navarro et al. (2007) reported that MJs are regulators of rubisco activity as well as the synthesis of other chloroplast proteins responsible in photosynthesis.

Also, MJs treatment appeared to arrest the growth, impaired leaf gas-exchange attributes and caused the loss of chlorophyll contents of soybean plants under water deficit (Anjum et al., 2011). It is reported that the MJs increased leaf area, photosynthetic pigments and decreased chlorophyll fluorescence in Phaseolus coccineus plants (Hanaka et al., 2015). Wierstra and Kloppstech (2000) reported that MJs declined the light-harvesting complex II (LHC II) and small subunit of Rubisco (SSU) transcript and $\mathrm{D}_{1}$ protein levels. The reduction in $\mathrm{D}_{1}$ levels of $\mathrm{MJs}$ treated leaf-segments might be due in part to the diminished

Table 3. Effect application of BRs concentration on photosynthetic pigments, chlorophyll fluorescence parameters and biomass of fennel (Foeniculum vulgar Mill) leaves

\begin{tabular}{|c|c|c|c|c|c|c|c|c|c|c|}
\hline \multirow{2}{*}{\multicolumn{2}{|c|}{ Characteristic }} & \multicolumn{5}{|c|}{ BRs concentration $(\mu \mathrm{M})$} & \multirow{2}{*}{ F value } & \multirow{2}{*}{ Estimated function } & \multirow{2}{*}{$\mathrm{R}^{2}$} & \multirow{2}{*}{$\begin{array}{c}\text { RMS } \\
\text { E }\end{array}$} \\
\hline & & 0 & 0.001 & 0.01 & 0.1 & 1 & & & & \\
\hline \multicolumn{11}{|c|}{ Major Chlorophyll } \\
\hline \multirow[t]{2}{*}{${ }^{\dagger}$ Chlorophyll a } & means & $1.70 \pm 0.32$ & $2.49 \pm 0.24$ & $2.82 \pm 0.11$ & $3.97 \pm 0.27$ & $3.04 \pm 0.08$ & $11.29^{* *}$ & $\begin{array}{c}\mathrm{Y}=1.86+3.55 \times \exp (-0.5 \times(\ln (\mathrm{x} / 31.2) / \\
\left.\left.2.38)^{2}\right) / \mathrm{x}\right)\end{array}$ & 0.916 & 0.47 \\
\hline & $\%$ & - & 46.5 & 65.7 & 133.3 & 79.0 & & & & \\
\hline \multirow{2}{*}{${ }^{\dagger}$ Chlorophyll b } & means & $0.53 \pm 0.19$ & $1.03 \pm 0.15$ & $1.20 \pm 0.29$ & $1.69 \pm 0.42$ & $1.69 \pm 0.59$ & $2.80^{\mathrm{ns}}$ & $Y=0.66+1.02 \times x /(0.005+x)$ & 0.913 & 0.20 \\
\hline & $\%$ & - & 95.1 & 126.0 & 218.5 & 219.2 & & & & \\
\hline \multirow{2}{*}{$\begin{array}{l}{ }^{\dagger} \text { Total } \\
\text { chlorophyll }\end{array}$} & means & $2.23 \pm 0.48$ & $3.52 \pm 0.19$ & $4.01 \pm 0.37$ & $5.65 \pm 0.68$ & $4.73 \pm 0.66$ & $7.35^{* *}$ & $\left.Y=2.33+53.7 \times \exp \left(-0.5 \times(\ln (x / 213) / 3.09)^{2}\right) / x\right)$ & 0.938 & 0.64 \\
\hline & $\%$ & - & 58.0 & 80.0 & 153.6 & 112.2 & & & & \\
\hline \multicolumn{11}{|c|}{ Accessory Pigments } \\
\hline \multirow{2}{*}{${ }^{\dagger}$ Carotenoids } & means & $0.55 \pm 0.08$ & $0.40 \pm 0.20$ & $0.53 \pm 0.17$ & $0.78 \pm 0.09$ & $0.62 \pm 0.13$ & $4.60^{*}$ & $\left.Y=0.47+0.14 \times \exp \left(-0.5 \times(\ln (x / 1.29) / 1.44)^{2}\right) / x\right)$ & 0.865 & 0.10 \\
\hline & $\%$ & - & -26.1 & -2.9 & 42.9 & 13.6 & & & & \\
\hline \multirow{2}{*}{${ }^{\dagger}$ Anthocyanin } & means & $0.55 \pm 0.08$ & $0.62 \pm 0.12$ & $0.48 \pm 0.05$ & $0.29 \pm 0.11$ & $0.40 \pm 0.03$ & $1.93^{\mathrm{ns}}$ & ns & - & - \\
\hline & $\%$ & - & 13.2 & -13.0 & -47.7 & -27.6 & & & & \\
\hline \multirow{2}{*}{${ }^{\dagger \dagger}$ Flavonoids } & means & $3.49 \pm 0.51$ & $4.42 \pm 0.73$ & $4.70 \pm 0.55$ & $5.03 \pm 0.42$ & $4.98 \pm 0.66$ & $1.56^{\mathrm{ns}}$ & $Y=3.49+1.44 \times x /(0.0006+x)$ & 0.976 & 0.13 \\
\hline & $\%$ & - & 26.5 & 34.5 & 43.9 & 42.5 & & & & \\
\hline \multirow{2}{*}{${ }^{\dagger}$ Phenol } & means & $1.02 \pm 0.04$ & $1.10 \pm 0.01$ & $1.13 \pm 0.02$ & $1.09 \pm 0.03$ & $1.07 \pm 0.02$ & $4.71^{*}$ & ns & - & - \\
\hline & $\%$ & - & 8.2 & 10.8 & 6.8 & 15.4 & & & & \\
\hline \multicolumn{11}{|c|}{ Chlorophyll fluorescence } \\
\hline \multirow{3}{*}{ PSII } & means & $0.723 \pm 0.04$ & $0.773 \pm 0.0$ & $0.903 \pm 0.0$ & $0.790 \pm 0.01$ & $0.763 \pm 0.02$ & $3.85^{*}$ & $Y=0.74+0.005 \times \exp (-0.5 \times(\ln (\mathrm{x} / 0.079) /$ & 0.958 & 0.02 \\
\hline & (1) & 0.120 .01 & 1 & 6 & 0.120 .0 .01 & 0.100 .0 .02 & (2) & $\left.\left.(1.37)^{2}\right) / \mathrm{x}\right)$ & & 7 \\
\hline & $\%$ & - & 6.92 & 24.90 & 9.27 & 5.53 & & & & \\
\hline \multirow{3}{*}{$\mathrm{qP}$} & means & $0.903 \pm 0.05$ & $0.947 \pm 0.0$ & $0.998 \pm 0.0$ & $1.003 \pm 0.06$ & $0.943 \pm 0.10$ & $9.93^{* *}$ & $\mathrm{Y}=0.90+0.079 \times \exp (-0.5 \times(\ln (\mathrm{x} / 17.12) /$ & 0.997 & 0.00 \\
\hline & means & 0.0070 .05 & 5 & 6 & $1.000 \pm 0.00$ & 0.770 .0 .10 & 1.. & $\left.\left.2.5)^{2}\right) / \mathrm{x}\right)$ & (0.0 & 4 \\
\hline & $\%$ & - & 4.87 & 10.52 & 11.07 & 4.43 & & & & \\
\hline \multirow{3}{*}{ NPQ } & means & $0.310 \pm 0.11$ & $0.157 \pm 0.1$ & $0.270 \pm 0.1$ & $0.387 \pm 0.11$ & $0.583 \pm 0.26$ & $1.1 \operatorname{lns}$ & $\mathrm{Y}=0.237+0.405 \times \mathrm{x} /(0.17+\mathrm{x})$ & 0.878 & 0.07 \\
\hline & & & 0 & 2 & & & & & & 84 \\
\hline & $\%$ & - & -49.5 & -12.9 & 24.7 & 88.2 & & & & \\
\hline \multirow{3}{*}{$\mathrm{F}^{\prime} \mathrm{v} / \mathrm{F}^{\prime} \mathrm{m}$} & means & $0.827 \pm 0.01$ & $0.880 \pm 0.0$ & $0.967 \pm 0.0$ & $0.800 \pm 0.04$ & $0.787 \pm 0.04$ & $2.54 \mathrm{~ns}$ & $\mathrm{Y}=0.8+0.038 \times \exp (-0.5 \times(\ln (\mathrm{x} / 0.003) /$ & 0.961 & 0.02 \\
\hline & & 0.027 .0 .01 & 4 & 6 & $0.000-0.01$ & & 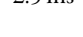 & $\left.\left.(0.38)^{2}\right) / \mathrm{x}\right)$ & & 8 \\
\hline & $\%$ & - & 6.41 & 16.93 & -3.26 & -4.84 & & & & \\
\hline \multirow{2}{*}{$\mathrm{Fv} / \mathrm{F}_{0}$} & means & $2.46 \pm 0.47$ & $3.03 \pm 0.44$ & $3.30 \pm 0.68$ & $3.24 \pm 2.14$ & $2.96 \pm 0.32$ & $1.61 \mathrm{~ns}$ & $\left.Y=2.46+11.6 \times \exp \left(-0.5 \times(\ln (x / 76.5) / 3.5)^{2}\right) / x\right)$ & 0.999 & $\begin{array}{c}0.01 \\
5\end{array}$ \\
\hline & $\%$ & - & 23.17 & 34.15 & 31.71 & 20.33 & & & & \\
\hline \multicolumn{11}{|c|}{ Growth plant } \\
\hline \multirow{3}{*}{${ }^{+t \dagger}$ Height plants } & means & $52.73 \pm 5.43$ & $53.00 \pm 3.6$ & $54.60 \pm 5.5$ & $57.40 \pm 8.70$ & $52.80 \pm 7.45$ & $0.65^{\mathrm{ns}}$ & $\left.Y=50.9+1.56 \times \exp \left(-0.5 \times(\ln (x / 0.78) / 1.56)^{2}\right) / x\right)$ & 0.78 & 282 \\
\hline & ting & 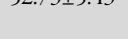 & 7 & 7 & & & & (1- & 7 & 2.02 \\
\hline & $\%$ & - & 0.5 & 3.5 & 8.9 & 0.1 & & & & \\
\hline \multirow{2}{*}{$\begin{array}{l}{ }^{\dagger} \text { Dry weight } \\
\text { plants }\end{array}$} & means & $7.21 \pm 0.68$ & $7.50 \pm 0.62$ & $8.51 \pm 1.21$ & $8.37 \pm 0.90$ & $7.35 \pm 0.83$ & $0.26^{\mathrm{ns}}$ & $\left.Y=7.2+0.191 \times \exp \left(-0.5 \times(\ln (x / 0.59) / 1.76)^{2}\right) / x\right)$ & $\begin{array}{c}0.99 \\
8\end{array}$ & 0.046 \\
\hline & $\%$ & - & 4.1 & 18.0 & 16.0 & 1.9 & & & & \\
\hline
\end{tabular}


carotenoids content as $\beta$-carotene is required for the assembly of $D_{1}$ protein into functional PSII reaction centres. It is suggested that MJs in developing leaves might play a role to prevent the formation of premature photosynthetic structures and accumulation of nutritive storage proteins for further leaf development.

Based on the obtained results, it is noted that among all of chlorophyll fluorescence parameters, only PSII, and qP were significantly affected by MJs (Table 4). The MJs increased these parameters, while the highest amount PSII, and $\mathrm{qP}$ by was observed in $50 \mu \mathrm{M}$ MJs (increased by $24 \%$ and $8 \%$ compared to control). The log-normal function was appropriate to describe the variation of PSII, and $\mathrm{qP}$ in treated plants with MJs (Table 4). Jin et al. (2011) showed that the foliar spraying of 0.2 and $0.5 \mathrm{mmol} \mathrm{MJs}$ exhibited the positive effects on mitigating the decrease of $\mathrm{Fv} / \mathrm{Fm}$, PSII, and $\mathrm{qP}$ and the increase of $\mathrm{qN}$ under drought stress. It is suggested that foliar application of MJs could alleviate the degradation of chlorophyll and play a definite role in protecting the PSII under drought stress, decrease the damage of drought stress on the seedlings, promote the rapid MJs recovery of chlorophyll fluorescence parameters after re-watering, and thus, ensure the regrowth of fluecured tobacco seedlings. Wierstra and Kloppstech (2000) stated that the increase of photochemical efficiency of PSII by MJs leads to an equilibrium between $\mathrm{D}_{1}$ destruction and repair which depends on the light intensity and a restoration phase during which PSII activity is recovered due to the integration of the newly formed $\mathrm{D}_{1}$ protein.

Application of MJs significantly increased the total dry weight of fennel plants, while this was not significant for plant height (Table 4). Change in plant dry weight was well explained by Gaussian function, with the slop of 17.8 and in $61 \mu \mathrm{M}$ MJs reached to maximum dry weight content.

Table 4. Effect application of MJs concentration on photosynthetic pigments, chlorophyll fluorescence parameters and biomass of fennel (Foeniculum vulgar Mill) leaves

\begin{tabular}{|c|c|c|c|c|c|c|c|c|c|c|}
\hline \multirow{2}{*}{ Characteristic } & & \multicolumn{5}{|c|}{ MJs concentration $(\mu \mathrm{M})$} & \multirow{2}{*}{ F value } & \multirow{2}{*}{ Estimated function } & \multirow{2}{*}{$\mathrm{R}^{2}$} & \multirow{2}{*}{ RMSE } \\
\hline & & 0 & 25 & 50 & 100 & 200 & & & & \\
\hline \multicolumn{11}{|c|}{ Major Chlorophyll } \\
\hline \multirow[t]{2}{*}{${ }^{\dagger}$ Chlorophyll a } & means & $1.70 \pm 0.32$ & $1.89 \pm 0.44$ & $3.25 \pm 0.41$ & $2.80 \pm 0.52$ & $2.59 \pm 0.50$ & $24.53^{* *}$ & $\begin{array}{c}\mathrm{Y}=1.6+174.7 \times \exp (-0.5 \times(\ln (\mathrm{x} / 152 .) / \\
\left.\left.0.78)^{2}\right) / \mathrm{x}\right)\end{array}$ & 0.926 & 0.34 \\
\hline & $\%$ & - & 11.0 & 91.0 & 64.7 & 52.5 & & & & \\
\hline \multirow[t]{2}{*}{${ }^{\dagger}$ Chlorophyll b } & means & $0.53 \pm 0.19$ & $0.46 \pm 0.23$ & $1.10 \pm 0.17$ & $1.12 \pm 0.20$ & $0.70 \pm 0.07$ & $6.92^{* *}$ & $\begin{array}{c}Y=0.49+66.9 \times \exp (-0.5 \times(\ln (x / 100.7) / \\
\left.\left..53)^{2}\right) / x\right)\end{array}$ & 0.939 & 0.15 \\
\hline & $\%$ & - & -12.5 & 108.4 & 110.9 & 32.8 & & & & \\
\hline \multirow[t]{2}{*}{${ }^{\dagger}$ Total chlorophyll } & means & $2.23 \pm 0.48$ & $2.35 \pm 0.64$ & $4.35 \pm 0.49$ & $3.92 \pm 0.72$ & $3.30 \pm 0.52$ & $23.1^{* *}$ & $\begin{array}{c}\mathrm{Y}=2.14+222 \times \exp (-0.5 \times(\ln (\mathrm{x} / 126) / \\
\left.\left.0.69)^{2}\right) / \mathrm{x}\right)\end{array}$ & 0.865 & 0.68 \\
\hline & $\%$ & - & 5.3 & 95.1 & 75.7 & 47.9 & & & & \\
\hline \multicolumn{11}{|c|}{ Accessory Pigments } \\
\hline \multirow[t]{2}{*}{${ }^{\dagger}$ Carotenoids } & means & $0.55 \pm 0.08$ & $0.59 \pm 0.02$ & $0.87 \pm 0.05$ & $0.80 \pm 0.09$ & $0.54 \pm 0.07$ & $4.26^{*}$ & $\begin{array}{c}Y=0.54+28.6 \times \exp (-0.5 \times(\ln (x / 80.4) / \\
\left.\left.0.45)^{2}\right) / x\right)\end{array}$ & 0.996 & 0.017 \\
\hline & $\%$ & - & 7.5 & 58.8 & 45.9 & -0.5 & & & & \\
\hline \multirow{2}{*}{${ }^{\dagger}$ Anthocyanin } & means & $0.55 \pm 0.08$ & $0.57 \pm 0.09$ & $0.49 \pm 0.05$ & $0.38 \pm 0.09$ & $0.41 \pm 0.12$ & $4.03^{*}$ & $Y=0.39+0.18 \times \exp \left(-.5 \times((x-17.8) / 28.1)^{2}\right)$ & 0.984 & 0.02 \\
\hline & $\%$ & - & 4.7 & -10.9 & -30.6 & -25.8 & & & & \\
\hline \multirow[t]{2}{*}{${ }^{\dagger \dagger}$ Flavonoids } & means & $3.49 \pm 0.51$ & $3.57 \pm 0.35$ & $4.75 \pm 0.42$ & $4.23 \pm 0.51$ & $4.09 \pm 0.54$ & $3.88^{*}$ & $\begin{array}{c}\mathrm{Y}=3.49+100 \times \exp (-0.5 \times(\ln (\mathrm{x} / 109) / \\
\left.\left.0.66)^{2}\right) / \mathrm{x}\right)\end{array}$ & 0.747 & 0.51 \\
\hline & $\%$ & - & 2.3 & 35.9 & 21.1 & 17.0 & & & & \\
\hline \multirow{2}{*}{${ }^{\dagger}$ Phenol } & means & $1.02 \pm 0.04$ & $1.13 \pm 0.05$ & $1.15 \pm 0.01$ & $1.15 \pm 0.03$ & $1.15 \pm 0.04$ & $3.51^{\mathrm{ns}}$ & $Y=1.01+0.13 \times x /(3.99+x)$ & 0.996 & 0.005 \\
\hline & $\%$ & - & 11.4 & 12.7 & 13.4 & 12.7 & & & & \\
\hline \multicolumn{11}{|c|}{ Chlorophyll fluorescence: } \\
\hline \multirow{2}{*}{ PSII } & means & $0.723 \pm 0.04$ & $0.797 \pm 0.01$ & $0.893 \pm 0.06$ & $0.793 \pm 0.00$ & $0.763 \pm 0.02$ & $3.87^{*}$ & $Y=0.74+0.175^{*} \exp \left(-.5^{*}((x-62.7) / 23.23)^{\wedge} 2\right)$ & 0.933 & 0.032 \\
\hline & $\%$ & - & 10.24 & 23.51 & 9.68 & 5.53 & & & & \\
\hline \multirow{2}{*}{$\mathrm{qP}$} & means & $0.903 \pm 0.05$ & $0.933 \pm 0.02$ & $0.970 \pm 0.02$ & $0.967 \pm 0.02$ & $0.910 \pm 0.02$ & $4.90^{*}$ & $Y=0.90+0.089 \times \exp \left(-.5 \times((x-73.8) / 30.09)^{2}\right)$ & 0.979 & 0.009 \\
\hline & $\%$ & & 3.32 & 7.42 & 7.09 & 0.78 & & & & \\
\hline \multirow{2}{*}{ NPQ } & means & $0.310 \pm 0.11$ & $0.257 \pm 0.06$ & $0.400 \pm 0.02$ & $0.363 \pm 0.08$ & $0.327 \pm 0.03$ & $1.10^{\mathrm{ns}}$ & ns & - & - \\
\hline & $\%$ & - & -17.2 & 29.0 & 17.2 & 5.4 & & & & \\
\hline \multirow[t]{2}{*}{$\mathrm{F}^{\prime} \mathrm{v} / \mathrm{F}^{\prime} \mathrm{m}$} & means & $0.827 \pm 0.01$ & $0.833 \pm 0.00$ & $0.967 \pm 0.06$ & $0.823 \pm 0.01$ & $0.820 \pm 0.02$ & $3.49^{\text {ns }}$ & $\begin{array}{c}\mathrm{Y}=0.82+0.03 \times \exp (-0.5 \times(\ln (\mathrm{x} / 0.004) / 0.35) \\
2) / \mathrm{x})\end{array}$ & 0.998 & 0.005 \\
\hline & $\%$ & - & 0.73 & 16.93 & -0.48 & -0.85 & & & & \\
\hline \multirow[t]{2}{*}{$\mathrm{Fv} / \mathrm{F} 0$} & means & $2.46 \pm 0.47$ & $2.51 \pm 0.22$ & $3.06 \pm 0.23$ & $2.37 \pm 0.10$ & $2.29 \pm 0.22$ & $1.49^{\mathrm{ns}}$ & $\begin{array}{c}\mathrm{Y}=2.3+0.16 \times \exp (-0.5 \times(\ln (\mathrm{x} / 0.004) / \\
\left.\left.0.36)^{2}\right) / \mathrm{x}\right)\end{array}$ & 0.960 & 0.12 \\
\hline & $\%$ & - & 2.03 & 24.39 & -3.66 & -6.91 & & & & \\
\hline \multicolumn{11}{|c|}{ Growth plant } \\
\hline \multirow{2}{*}{${ }^{+\dagger+}$ Height plants } & means & $52.73 \pm 5.43$ & $52.82 \pm 2.71$ & $53.00 \pm 4.16$ & $49.80 \pm 4.89$ & $48.40 \pm 3.75$ & $1.01^{\mathrm{ns}}$ & $Y=43.4+9.7 \times \exp \left(-.5 \times((x-26.9) / 80.48)^{2}\right)$ & 0.996 & 0.42 \\
\hline & $\%$ & - & 0.17 & 0.51 & -5.56 & -8.2 & & & & \\
\hline \multirow{2}{*}{${ }^{\dagger}$ Dry weight plants } & means & $7.21 \pm 0.68$ & $7.53 \pm 0.71$ & $10.48 \pm 1.25$ & $7.38 \pm 0.25$ & $6.81 \pm 0.67$ & $6.49^{*}$ & $Y=6.99+4.21 \times \exp \left(-.5 \times((x-61.03) / 17.8)^{2}\right)$ & 0.991 & 0.27 \\
\hline & $\%$ & - & 4.4 & 45.4 & 2.3 & -5.5 & & & & \\
\hline
\end{tabular}


514

\section{Conclusions}

The study proved that the effects of PGRs on major chlorophyll was more pronounced compared to accessory pigments, although among all the chlorophyll fluorescence parameters, only PSII was influenced by all of the PGRs. The present findings showed that the exogenous application of $0.5 \mathrm{mM}$ Put, $0.1 \mu \mathrm{M}$ BRs and $50 \mu \mathrm{M}$ MJs provided the optimum concentrations of PGRs to improve photosynthetic indices of fennel plants. Among PGRs, only MJs exhibited the significant effects on the growth and development of fennel.

\section{References}

Akram NA, Ashraf M (2013). Regulation in plant stress tolerance by a potential plant growth regulator, 5-aminolevulinic acid. Journal of Plant Growth Regulation 32(3):663-679.

Alcázar R, Altabella T, Marco F, Bortolotti C, Reymond M, Koncz C, Tiburcio AF (2010). Polyamines: molecules with regulatory functions in plant abiotic stress tolerance. Planta 231(6):1237-1249.

Anjum SA, Xie XY, Farooq M, Wang LC, Xue LI, Shahbaz M, Salhab J (2011). Effect of exogenous methyl jasmonate on growth, gas exchange and chlorophyll contents of soybean subjected to drought. African Journal of Biotechnology 10(47):9647-9656.

Anuradha S, Rao SER (2011). Amelioration of lead toxicity in radish (Raphanus sativus L) plants by brassinolide. Journal of Applied Biological Sciences 3:43-48.

Anuradha S, Rao SSR (2003). Application of brassinosteroids to rice seeds (Oryza sativa L.) reduced the impact of salt stress on growth, prevented photosynthetic pigment loss and increased nitrate reductase activity. Plant Growth Regulation 40(1):29-32.

Aprotosoaie AC, Spac A, Hancianu M, Miron A, Tanasescu VF, Dorneanu V, Stanescu U (2010). The chemical profile of essential oils obtained from fennel fruits (Foeniculum vulgare Mill.). Farmacia 58(1):46-53.

Araújo WL, Nunes-Nesi A, Osorio S, Usadel B, Fuentes D, Nagy R, Martinoia E (2011). Antisense inhibition of the iron-sulphur subunit of succinate dehydrogenase enhances photosynthesis and growth in tomato via an organic acid-mediated effect on stomatal aperture. The Plant Cell tpc-110.

Arnon AN (1967). Method of extraction of chlorophyll in the plants. AgronomyJournal 23:112-121.

Arnon DI (1949). Copper enzymes in isolated chloroplasts. Polyphenoloxidase in Betavulgaris. Plant Physiology 24(1):1-15.

Asgher M, Khan MIR, Anjum NA, Khan NA (2015). Minimising toxicity of cadmium in plants-role of plant growth regulators. Protoplasma 252(2):399-413.

Bajguz A (2000). Blockade of heavy metals accumulation in Chlorella vulgaris cells by 24-epibrassinolide. Plant Physiology and Biochemistry 38(10):797-801.

Bari R, Jones JDG (2009). Role of plant hormones in plant defence responses. Plant Molecular Biology69(4):473-488.

Berry PM, Sylvester-Bradley R, Berry S (2007). Ideotype design for lodgingresistant wheat. Euphytica 154(1-2):165-179.
Cevahir G, Yentür S, Eryilmaz F, Yilmazer N (2008). Influence of brassinosteroids on pigment content of Glycine max L. (soybean) grown in dark and light. Journal of Applied Biological Sciences 1:23-28.

Diao W-R, Hu Q-P, Zhang H, Xu J-G (2014). Chemical composition, antibacterial activity and mechanism of action of essential oil from seeds of fennel (Foeniculum vulgare Mill.). Food Control 35(1):109-116.

Díaz-Maroto MC, Pérez-Coello MS, Esteban J, Sanz J (2006). Comparison of the volatile composition of wild fennel samples (Foeniculum vulgare Mill.) from Central Spain. Journal of Agricultural and Food Chemistry 54(18):6814-6818.

Eyidogan F, Oz MT, Yucel M, Oktem HA (2012). Signal transduction of phytohormones under abiotic stresses. In: Phytohormones and Abiotic Stress Tolerance in Plants. Springer, pp 1-48.

Fariduddin Q, Yusuf M, Ahmad I, Ahmad A (2014). Brassinosteroids and their role in response of plants to abiotic stresses. Biologia Plantarum 58(1):9-17.

Fletcher R, Kott LS (1999). Phenolics and cold tolerance of Brassica napus. Proc 10th Int Rapeseed Congr GCIRC, Canberra, Australia.

Hanaka A, Maksymiec W, Bednarek W (2015). The effect of methyl jasmonate on selected physiological parameters of copper-treated Phaseolus coccineus plants. Plant Growth Regulation 77(2):167-177.

Hasanuzzaman M, Nahar K, Fujita M (2014). Regulatory role of polyamines in growth, development and abiotic stress tolerance in plants. Plant Adaptation to Environmental Change: Significance of Amino Acids and Their Derivatives 157-193.

Hashmi N, Khan MMA, Idrees M, Khan ZH, Ali A, Varshney L (2012). Depolymerized carrageenan ameliorates growth, physiological attributes, essential oil yield and active constituents of Foeniculum vulgare Mill. Carbohydrate Polymers 90(1):407-412.

Hayat S, Alyemeni MN, Hasan SA (2012). Foliar spray of brassinosteroid enhances yield and quality of Solanum bycopersicum under cadmium stress. Saudi Journal of Biological Sciences 19(3):325-335.

Houimli SIM, Denden M, El HadjS Ben (2008). Induction of salt tolerance in pepper (Capsicum annuum) by 24 epibrassinolide. EurAsian Journal of BioSciences 1(2):83-90.

Igarashi K, Kashiwagi K (2000). Polyamines: mysterious modulators of cellular functions. Biochemical and Biophysical Research Communications 271(3):559-564.

Jin W-W, Wang Y, Zhang H-H, Zhi-Li J, Peng W, Xin L, Guang-Yu S (2011). Effects of foliar spraying methyl jasmonate on leaf chlorophyll fluorescence characteristics of flue-cured tobacco seedlings under drought and re-watering. The Journal of Applied Ecology 22(12):31573162.

KrizekDT, Britz SJ, Mirecki RM (1998). Inhibitory effects of ambient levels of solar UV-A and UV-B radiation on growth of cv. 'New Red Fire' lettuce. Physiologia Plantarum 103(1):1-7.

Mahfouz SA, Sharaf-Eldin MA (2007). Effect of mineral vs. biofertilizer on growth, yield, and essential oil content of fennel (Foeniculum vulgare Mill.).International Agrophysics 21(4):361-366.

Mahros KM, El-Saady MB, Mahgoub MH, AfafMH, El-Sayed MI(2011). Effect of putrescine and uniconazole treatments on flower characters and photosynthetic pigments of Chrysanthemum indicum. L plant. Journal of American Science 7:399-408. 
Marín-Navarro J, Manuell AL, Wu J, Mayfield SP (2007). Chloroplast translation regulation. Photosynthesis Research 94(2-3):359-374.

Nanvakenary R, Moradi H, Ghasemiomran S (2013). Effects of putrescine on morphological and physiological characteristics of ornamental plant African violet (Saintpaulia ionantha). Bulletin of Environment, Pharmacology and Life Science 2(10):118-122.

Navakoudis E, Vrentzou K, Kotzabasis K (2007). A polyamine-and LHCII protease activity-based mechanism regulates the plasticity and adaptation status of the photosynthetic apparatus. Biochimica et Biophysica Acta (BBA)-Bioenergetics 1767(4):261-271.

Piñol R, Simón E (2009). Effect of 24-Epibrassinolide on chlorophyll fluorescence and photosynthetic CO2 assimilation in Vicia faba plants treated with the photosynthesis-inhibiting herbicide terbutryn. Journal of Plant Growth Regulation 28(2):97-105.

Rascher U, Liebig M, Lüttge U (2000). Evaluation of instant light-response curves of chlorophyll fluorescence parameters obtained with a portable chlorophyll fluorometer on site in the field. Plant, Cell \& Environment 23(12):1397-1405.

Rather MA, Dar BA, Sofi SN, et al. (2016). Foeniculum vulgare: A comprehensive review of its traditional use, phytochemistry, pharmacology, and safety. Arabian Journal of Chemistry 9:S1574 S1583.

Shu S, Yuan L-Y, Guo S-R, Sun J, Liu CJ (2012). Effects of exogenous spermidine on photosynthesis, xanthophyll cycle and endogenous polyamines in cucumber seedlings exposed to salinity. African Journal of Biotechnology 11(22):60646074.
TangJ, Han Z, Chai J (2016). Q\&A: what are brassinosteroids and how do they act in plants. BMC Biology 14(1):1-5.

Vardhini BV, Anuradha S, Rao SSR (2006). Brassinosteroids-new class of plant hormone with potential to improve crop productivity. Indian Journal of Plant Physiology 11(1):1-12.

Wagner GJ (1979). Content and vacuole/extravacuole distribution of neutral sugars, free amino acids, and anthocyanin in protoplasts. Plant Physiology 64(1):88-93.

Wang Z-Y, Wang Q, Chong K, et al. (2006). The brassinosteroid signal transduction pathway. Cell Research 16(5):427-434.

Wierstra I, Kloppstech K (2000). Differential effects of methyl jasmonate on the expression of the early light-inducible proteins and other lightregulated genes in barley. Plant Physiology 124(2):833-844.

Yuan Y, Shu S, Li S, et al. (2014). Effects of exogenous putrescine on chlorophyll fluorescence imaging and heat dissipation capacity in cucumber (CucumissativusL.) under salt stress. Journal of Plant Growth Regulation 33(4):798-808.

Yuan Y, Zhong M, Shu S, Du, N, He L, Yuan L, Guo S (2015). Effects of exogenous putrescine on leaf anatomy and carbohydrate metabolism in cucumber (Cucumis sativus L.) under salt stress. Journal of Plant Growth Regulation 34(3):451-464.

Zhang L, Paakkarinen V, van Wijk KJ, Aro E-M (2000). Biogenesis of the chloroplast-encoded $D_{1}$ protein: regulation of translation elongation, insertion, and assembly into photosystem II. The Plant Cell 12(9):17691781. 